\title{
The Moderating Effects of Organizational Programs and Supervisor Support on Work - Family Balance: Evidence from Brazil
}

\author{
Rosario M. A. Miranda Mar ${ }^{1}$, Satyanarayana Parayitam²
}

\begin{abstract}
:
Research on work-family balance has received increasing attention by academicians and practitioners alike. The present study identifies some of the antecedents to work-family balance and the intervening factors that foster the work-family balance. Data was collected from 125 individuals (using a structured instrument) and interviews with a group of 13 individuals from the employees of a public sector institution of the Brazilian Federal Government. The hierarchical regression results indicated that organizational support programs, supervisor support moderated the relationship between type of work, workweek, number of children and age of children, whereas spouse support did not moderate the relationship. The implications for management and suggestions for future research are discussed.
\end{abstract}

\footnotetext{
${ }^{1}$ MBA Escola Brasileira de Administração Pública e de Empresas - Fundação Getúlio Vargas. 2011.

${ }^{2}$ Department of Management and Marketing, Charlton College of Business, University of Massachusetts Dartmouth, sparayitam@umassd.edu
} 


\section{Introduction}

Research on work-family balance has received increasing attention by academicians and practitioners alike. The underlying argument is work-family balance contributes to individual well-being and promotes healthy society (Halpern, 2005). Apart from academicians, the popular periodicals in press (e.g. Fortune, Newsweek, and Society for Human Resource Management) focus on providing some material that fosters work-family balance (Grzywacz \& Carlson, 2007). Early researchers focused mainly on the work-family conflicts. The researchers contend that work and family constitute two domains of every individual and, when demands and expectations of one domain are incompatible with the demands and expectations of the other domain, conflict occurs (Greenhaus \& Beutell, 1985). The proliferation of research on the work-home interface revealed examination of work-to-family conflict (WFC) and family-to-work conflict (FWC) and noted that these are influenced by each other (Bellavia \& Frone, 2005; Ford, Heinen, \& Langkamer, 2007; Voydanoff, 2005). Countless empirical studies and review articles examined the antecedents of both WFC and FWC and postulated various models integrating the WFC framework (Carlson \& Frone, 2003; Parayitam \& Kalra, 2008). Both academicians and practitioners strongly started believing that WFC is very important because, if not properly managed, the conflict has deleterious consequences on both organizations and individuals (Bedeian et al, 1988; Frone et al., 1992a; Frone et al., 1992b; Rice et al, 1992, Frone and Yardley, 1996, Frone et al, 1997, McFarland, 2004). Some of the widely researched negative consequences of WFC are job dissatisfaction, burnout, deteriorating relationships, life dissatisfaction. For example, the researchers demonstrated that the work-family conflict has negative relationship with job satisfaction and has been a major concern for the managers (Frone et al, 1992a; Frone et al, 1992b; Kopelman et al, 1983). Some researchers contend that gender moderates the relationship between WFC and job satisfaction such that women show a lower level of job satisfaction when compared to men (Calvo-Salguero, CarrascoGonzalez, \& Salinas-Martinez de Lecea, 2010).

Contrary to the early researchers who focused on work-family conflict, contemporary researchers attempted to focus on work-family balance. In other words, a further refinement of the concept lead to the positive side of viewing the conflict in terms of balance. Work-family balance represents absence of work-family conflict. Based on the role balance theory (Marks \& MacDermid, 1996), Greenhaus, Collins \& Shaw (2003) defined work-family balance as "the extent to which individuals are equally engaged in and equally satisfied with work and family roles" (p. 513). Another comprehensive definition offered by Voydanoff (2005) is that work-family balance is "a global assessment that work resources meet family demands, and family resources meet work demands such that participation is effective in both domains" (p. 825). Essentially, when individual is getting satisfied with the work and also effective in family roles work-family balance is maintained (Clark, 2000; Kirchmeyer, 2000; Greenhaus \& Allen, 2006).The present study focuses on the work-family balance, which represents the extent to which an individual experiences fulfilment in both work and home. With an increasing role of 
women at the workplace, the pressures of maintaining both work and family are on both spouses (when both spouses are working) make the work-family balance a challenge. Present-day technology and convenience are making it possible for organizations to help the individuals maintain happy work-family balance in terms of offering them opportunity of flextime, work from home, telecommuting etc.

Early researchers on work-life balance emphasized the relevance of the concept to women with children. However, researchers tend to agree that this concept is relevant to men and also for singles or couples without children. Doing multiple roles exhaust the individual of time and effort and make them psychologically distressed. Research demonstrated that organizational policies, cultural norms, organizational climate, supervisors and co-workers, play a significant role in workfamily balance of employees (Kossek, Baltes, \& Matthews, 2011). Since workfamily balance is opposite to work-family conflict, it is necessary to understand the forms of work-family conflict. Extant research revealed three forms of work-family conflict viz., strain-based conflict, behavior-based conflict, and time-based conflict (Greenhaus \& Beutell, 1985). When an individual manages these conflicts it is easy to maintain the work-family balance. When an individual faces strain or stress at work, he/she would not be able to discharge family responsibilities (referred to as strain-based conflict), and when an individual encounters behavioral problems with colleagues and his/her boss, the consequence is behavior-based conflict, which has deleterious consequences on work-family balance. Finally, the time-based conflict arises when individuals are set to achieve performance targets on time. Thus, degree to which an individual balances the time, stress, and behavioral demands of work and is able to fulfil the family responsibilities is necessary for happy and successful life (Hill et al, 2001). Some researchers contend that work-family balance results in work-family fit (Clarke et al 2004). To maintain balance between work and family it is imperative to reduce these three types of conflict.

Research on work-family balance in the recent past has showcased some insights into theoretical directions (Westman, Brough \& Kalliath, 2009). One of the important insights was that emotional fallout from workplace experiences can be transferred to the spouse, children and family members (Westman, Brough, \& Kalliath, 2009). Some scholars suggest that the impact of work-family conflicts on job satisfaction and turnover was stronger in Anglo countries like The US, The UK, Australia, New Zealand, than in Asia, Latin America, and Eastern Europe (Powell, Francesco \& Ling, 2009; Spector et al, 2007). Therefore, cross-cultural differences suggest that the work-family balance is subject to culture sensitivity. Many of the recent studies demonstrated the effect of work-family balance on health and job performances. For example, the impact of work-family conflicts, and facilitation experiences on cholesterol level and body mass index was studied and the results revealed that employees who experience low level of conflict have higher levels of health, lower absenteeism, and better organizational performance (van Steenbergen \& Ellemers, 2009). 
For achieving work-family balance, organizations need to promote family-friendlywork-practices (FFWPs). One study focused exclusively on FFWPs and demonstrated that top management support to promote programs facilitating work practices positively affected the organizational climate, which, in turn, influenced organizational performance and turnover (Ngo, Foley, \& Foi, 2009).

Work-family balance is beneficial to both individuals and organizations. To the organization, the benefits include reducing absenteeism and turnover, enhanced organization image, retention of valuable employees, securing employee loyalty and commitment, and improved productivity (Lazar, Osoian, \& Ratiu, 2010). From the viewpoint of the employee, benefits include lower stress levels and more physical and mental health, enhanced control over both work and life, a greater sense of job security and increased level of job satisfaction (Lazar, Osoian, \& Ratiu, 2010).

In the conceptual model presented here, we argue that type of work, workweek in terms of number of hours, and role of individual in organization (managerial or nonmanagerial role) influence the work-family balance. In addition, the number of children and age of children also have a bearing on the work-family balance.

\section{CONCEPTUAL MODEL AND DEVELOPMENT OF HYPOTHESES}

\section{Type of work and work-family balance}

The state of equilibrium between a person's job demands and family responsibilities largely depends on the type of work done in organizations. Type of work has direct impact on the number of hours devoted to work. For example, managerial positions require considerable amount of time in organizations and leaving less time for families (Frone et al, 1992a; Tremblay, 2004). Similarly, lower-level positions and blue-collar positions leave substantial amount of time for individuals to take care of family responsibilities. Interviews from the employees of Federal Court of Accounts in Brazil (called Tribunal de Contas da União - TCU) revealed that people who occupy management or advisory positions do not have reduced workweek. Most of the time is spent in business meetings and often managers need to work over and above eight hours per day. This makes them have less time to devote to the tasks related to family care. A women employee who was interviewed claimed that she needed to stay more hours at the workplace due to the management position she occupies and confessed that it generated some degree of work-family conflict and disrupted work-family balance. Surprisingly, on the contrary, two men who were interviewed who occupied management positions mentioned that nature of their job did not disturb their work-family balance because their spouses took care of the family responsibilities.

Secondly, employees who do not occupy managerial positions did not face the problem of work-family balance because the work is highly predictable and there were no uncertainties of their availability at home. Finally, positions that are interdependent also decrease work-family balance because the nature of work is such 
that the performance of one individual depends on the availability of another individual. Based on the above it is hypothesized:

H1: Type of work is negatively related to work-family balance.

\section{Workweek and work-family balance}

The longer the workweek, the lesser the work-family balance will be. A way of facilitating the relationship between work and family is the usage of strategies that facilitates the adaptation between both work and family, and one of the necessary ways is to have reduced workweek (Tremblay, 2003). In organizations, though the standard norm is to have 40-hour workweek, a differentiated workweek of 30 to 35 hours is practiced depending on the position of employees in the organizational ladder. Employees in managerial and advisory positions have a 40-hour workweek and people in lower-rungs work less than 40 hours.

Interviews of employees revealed that those do not occupy management or advisory positions were satisfied with the reduced workweek, because they like to use this additional time, that is, an extra hour per day, in order to perform activities demanded by the family role. For instance, a female subject who was interviewed, when asked specifically about the organization of her daily schedule, said: "I work seven hours per day. During part of that time, my children are at school (about four and a half hours), and then they stay with a babysitter (a little bit more than three hours). Therefore, the time I cannot dedicate to them, because I am working, is a fairly short time. It is really an advantage in order to organize my time." Additionally, the same female subject said she does not perceive work-family conflict, due to the possibility of organizing her schedule so as to give attention to both demands. She said: "The seven-hour period I work each day allows me to have more time in order to organize myself for working, as well as for taking care of my family responsibilities". In a similar way, another female subject who was interviewed and whose baby is less than one year old stated she is satisfied with the possibility of working less than eight hours per day, because that allows her to stay less time away from home. The same female subject informed that, when she is away from home, her mother takes care of her baby, remarking that she feels satisfied with that care, since her mother gives her confidence. On the other hand, a third female subject who was interviewed and who occupies a management position said she devotes approximately nine and a half hours to work per day. She stated that sometimes she would like to spend more time with her son, because being a manager demands more time from her, as compared to a hypothetical situation in which she would not be a manager.

Based on the information obtained through the interviews, it was observed that a shorter workweek allows the employee to dedicate more time to the family demands. That was particularly clear in the cases of women with young children, who value the possibility of having more time available, since the requirements of younger children are apparently bigger than those of older ones. Moreover, even when they can count on other people's support in order to satisfy those needs, the women who 
were interviewed would prefer to do that by themselves in a personal way, so as to participate in the greatest amount of tasks possible.

Based on the above, it can be hypothesized that:

$\mathrm{H} 2$ : Longer workweek is negatively related to work-family balance.

\section{Number of children and work-family balance}

Size of family in terms of number of children has some effect on the work-family balance. It is expected that increase in the size of family (more children) exerts lot of pressure for both spouses to focus on family responsibilities. The subjects that have only one child expressed that there is no problem of work-family balance whereas subjects that have more children confessed that they have to devote more time to family (Chenevier, 1996). There was only one female subject that expressed having made some important decisions regarding that matter, when she said: "I decided to have only one child so as to have enough time to better perform my multiple roles." Though there was no prior research on the impact of number of children on workfamily balance, available evidence from interviews suggest the following hypothesis:

H3: Number of children is negatively related to work-family balance.

\section{Age of youngest child and work-family balance}

While children grow older, work-family balance becomes easier (Tremblay, 2004). Based on Tremblay's (2004) observations, interviews were conducted with the parents who have children older than pre-school age range. In the process of interviews, the subjects analyzed and compared the previous stage (younger children at pre-school age) and the current stage (older children at school age). The subjects considered pre-school stage as a period in which there is a greater demand of physical presence in order to develop their roles. Care and attention demanded by children during that period urged parents to be more physically present, as well as to have the obligation of counting on other people to help them. That made them be absent from work more frequently and less predictably, which also made them feel bad in some situations. One female subject said: "When my children were younger, they needed me to be more present. Even when I had really good housekeepers, I needed to be at home in order to monitor and take care of their basic needs." Afterwards, the same female subject said that she needed to book more medical appointments, both planned and unplanned due to emergencies, which made her sometimes be absent from work.

The subject affirmed: "When my children were younger, I needed to get a medical certificate, when I had to take care of my children, but I found that unpleasant because I felt like cheating on the institution..." This last situation is because, in previous years, there was no such thing as hour bank, which allows employees to compensate time not worked on different. The same subject mentioned the need for parents to be present in order to assume the role of child formation as an important part of her role as a mother. In that sense, she said that "when children are younger, they need their parents to show them the right way to go, to teach them that life has 
limits... When they grow older, they tend to act more independently, since they have the fundamentals that were taught to them." This argument was presented in order to motivate her idea that her children, now teenagers, demand less time and less presence from her.

A male subject said that his children, also teenagers, demand less time and less presence from him because now they have their own activities, which are more numerous and exclude their father, even considering that he said this: "I try to participate in the lives of my children. I am with them in all events I can participate, but nowadays their lives have many activities, and I cannot take part in many of them. I just try to know what is going on with them through frequent dialogs with them."

Based on these interviews, it is observed that children ages effectively influence work-family balance. It must be stressed that, in order to obtain a more precise reference, the youngest child must be observed, since this child is the one that, at last, as far as their older siblings are concerned, will be leaving the most demanding stages behind. In that sense, the younger the youngest child is, the more he or she will demand from his or her parents. Therefore, this could potentially generate lack of work-family balance situations. Based on the above it can be hypothesized: H4: Age of youngest child is positively related to work-family balance.

\section{Supervisor support as a moderator in the relationship between type of work and workweek and work-family balance}

Since one third of the life of individuals is spent in organizations, supervisor support plays a vital role in maintaining work-family balance. Supervisors are in a position to encourage or discourage the employees because they have authority to sanction or limit the use of organizational programs that benefit the employees (Guerin et al., 1997). If supervisors enthusiastically support the integration of paid work and other responsibilities, employees can make use of organizational programs such as flextime, compressed workweek, and telecommuting etc., (Lazar, Osoian and Ratiu, 2010). On the contrary, if managers send negative signals about the use of these programs and suggest that it becomes a problem for the organization, employees will feel that supervisor's support is less (Hudson Resourcing, 2005).

In the interviews conducted, the subjects expressed that the supervisor support with regard to authorization to use telework and flexible schedule are very important to enhance work-family balance. For example, one research subject mentioned that it is possible to share the execution of family tasks with his wife because he is currently using telework. Thus, the subject affirmed to count on the support of his manager in order to have a good professional performance, without leaving his family needs unattended. He also said that his managers are extremely sensitive to his family problems and needs. The subject mentioned in the interview: "My manager is very flexible as far as my family needs are concerned, allowing me to change my normal working routine so that I can give attention to the needs of my family." Thus, based on the above the following are hypothesized: 
H1a: Supervisor support programs moderates the relationship between type of work and work-family balance such that higher support leads to higher work family balance.

H2a: Supervisor support moderates the relationship between workweek and workfamily balance such that higher support leads to higher work family balance.

\section{Organizational support programs and work-family balance}

The changing nature of work over the last decade necessitates the launching of several organizational support programs to facilitate employee efforts to meet the demands at work and at home. Literature review indicates that there are several family friendly policies which include flexible working hours, part-time work, compressed workweeks telecommuting, on-site childcare facility, job sharing and parental leave (Harter, Schmidt \& Keyes, 2002). Flexi time allows employees to start their job at their convenient time and complete the working day so that they can meet their personal commitments and family responsibilities. Technological advancements provided opportunities for the employees to do their regular work from home thereby saving several man-hours of commuting time. Telecommuting has become popular in several companies in western world. Another support program is compressed workweek which can be seen in terms of reduction in number of working days. This is generally done on a weekly or bi-weekly basis and this allows employees to have mini-vacations and fulfil their household responsibilities.

The interviews about the organizational programs revealed interesting facts. For example, one female subject said: "Flextime allows me to better manage my time, according to the needs of family and work." Another female subject said: "Flextime allows me to reconcile the time needed to attend the family and work requirements". Another employee said:

"In the past, it was more difficult to reconcile my family tasks, especially those ones related to taking care of my children, with those ones related to work, because there were not flexible working measures such as the current ones. On the contrary, the control of working hours was very strict. Back then [when her children were younger], when I needed to take care of my children due to health problems, I needed to ask for medical certificates, which was a legitimate and authorized option, but which made me feel uncomfortable. After the implementation of the hour bank, I felt much better because I could do the things that were necessary in order to take care of my children because afterwards I would be able to compensate those hours. Even if I had to work late on a specific day, I would not suffer, because I was doing my duty. That allowed me to be freed from the old sensations that I had for cheating on the institution in order to be absent in my regular working hours."

Another subject remarked: 
"As my wife also works and does not have free time, telework gave me the possibility of completely assuming the task of taking care of my children as far as taking them to school, picking them up at school and taking them back home, taking them to their colleagues' homes, picking them up there and bringing them back home, going with them to the extracurricular activities and so on, all of those activities reconciled in a harmonic way with my responsibilities at work."

These are consistent with research that the organizational programs constitutes a form of redefining the expectations of employees and organizations (Hall, 1972). Some big organizations have daycare/childcare centers to meet the need of employees. For example, in Star City Casino in Sydney provides a twenty-four hour childcare facility that helped the employees to attain work-family balance. Management has reported that this childcare facility significantly reduced the employee turnover. Based on the above, the following are hypothesized:

H1b: Organizational support programs moderates the relationship between type of work and work-family balance such that higher support leads to higher work-family balance.

$\mathrm{H} 2 \mathrm{~b}$ : Organizational support programs moderates the relationship between workweek and work-family balance such that higher support leads to higher work-family balance.

\section{Spouse support and work-family balance}

Performance of employees in organizations also depends on the extent to which spouse supports at home. Spouse support is generally seen in terms of taking physical or emotional care of the other family members. Literature review reveals spouses that provide mutual support are protected from high family-work conflicts (Greenhaus \& Beutell, 1985). Within the group of interviewed research subjects, more than half reported that the household tasks are shared between the spouses, including childcare. This will enable them to focus on their professional responsibilities and personal needs. One female subject said: "Every day, my partner goes to school in order to pick our children up and afterwards he takes them home to have lunch. Thus, I can stay at work continuously and, as a consequence, I can leave my workplace earlier." Based on the above the following are hypothesized:

H3a: Spouse support moderates the relationship between number of children and work-family balance such that higher spouse support leads to higher work family balance.

H4a: Spouse support moderates the relationship between age of children and work-family balance such that higher spouse support leads to higher work family balance.

The conceptual model is presented in Figure 1. 


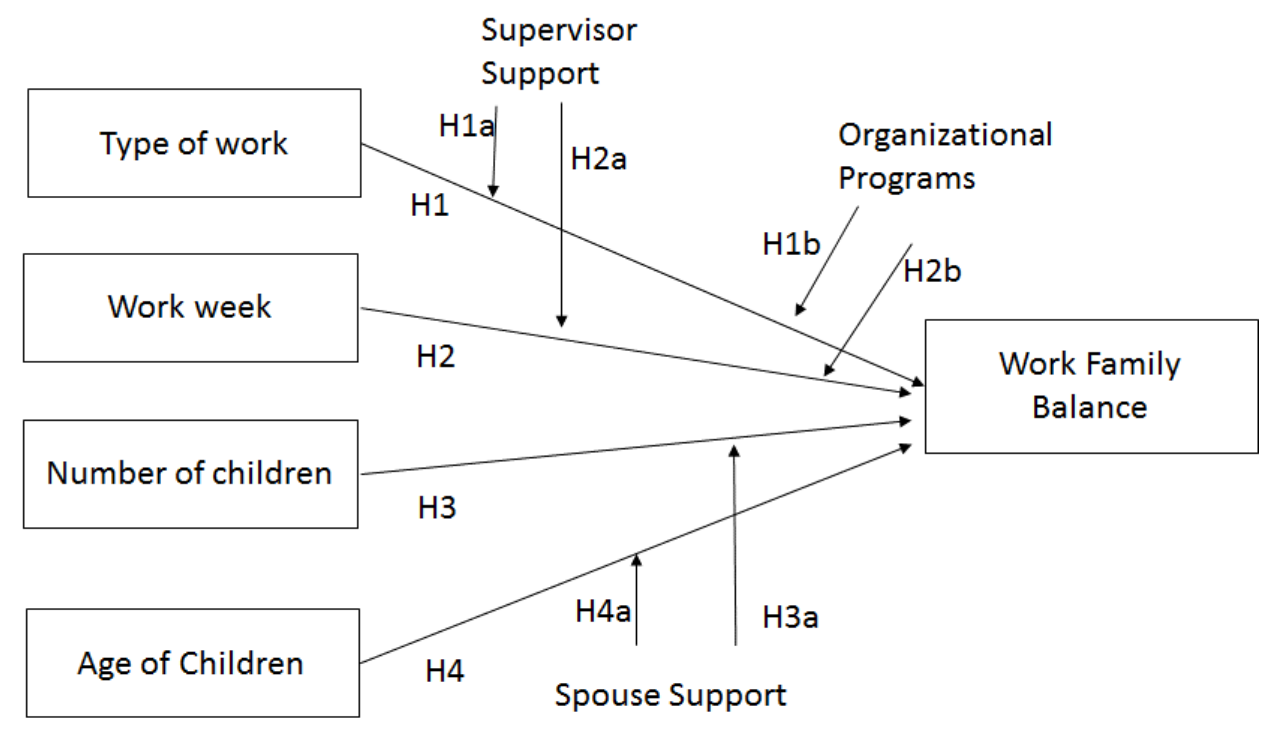

Control variables: Age, Gender, and Childcare

Figure 1. Conceptual Model

\section{METHODS}

\section{Sample}

This data was collected from the employees of Federal Court of Accounts in Brazil (called Tribunal de Contas da União - TCU). In addition to sending surveys, interviews were also conducted with some of the employees (Miranda, 2011). In all, 131 individuals participated in the survey out of which 6 surveys were incomplete. This leaves a total sample size of 125 of which 80 were men and 45 were women. The sample represents 6.72 percent of the total population. The average age of individuals was 44.86 years (standard deviation $=7.62$ ). The average age of women was 43.31 years (standard deviation $=6.42$ years old), and average age of men was 45.74 years old (standard deviation $=8.13$ years old $)$.

\section{Measures}

Type of work: Following Tremblay (2004) and Frone et al (1992a), type of work is measured using three categories viz., ' 0 ' representing 'no management/advisory position', '1' representing 'advisory position' and '2' representing 'management position'.

Workweek: Workweek is measured in terms of number of hours per week (Grzywacz et al, 2006). 
Number of children: This is measured using four categories: ' 0 ' representing no child; ' 1 ' representing one child, 2 for two children, 3 for three children, 4 represents 4 or more children (Tremblay, 2004).

Age of children: Measured using five categories (" 0 ") no child; ("1") less than 6 years old; ("2") between 6 and 12 years old; ("3") between 13 and 18 years old; ("4") more than 18 years old. This is used by previous researchers (Frone et al, 1992a; Frone et al, 1992b).

Organizational programs: This is measured asking whether organizations are using the programs such as: "Flextime"; "Hour bank"; "Telework"; "Childcare center at the workplace"; "Other". The quantitative indicators used were adapted from Chambel \& Santos (2009).

Supervisor support: Supervisor support at work was measured, on a five-point Likert-type scale, using two items adapted from Tremblay (2004) and Warren \& Johnson (1995). These items were: "Is your supervisor understanding as far as your family responsibilities are concerned?" and "Does your supervisor demonstrate flexibility as far as work schedule and other working conditions are concerned when you have family problems and needs?". The scale of responses for both questions is the same, where a higher Number represents more support: ("0") never; ("1") occasionally; (“2”) about half of the times; (“3”) frequently; (“4”) always.

Spouse support: Following Tremblay (2004), spouse support was measured using one item on a Likert-type five-point scale. The single item was: "Does your spouse/partner divide the domestic responsibilities with you?", having the following scale of responses: ("0") none; ("1") a few; ("2") approximately half of them; (“3”) many; (“4") all. A greater number represents more support.

Work-family balance: Work-family balance was measured on a five-point scale, ' 0 ' representing poor balance and ' 4 ' representing more strong work-family balance, using three items adapted from Tremblay (2004) and Frone et al (1992a). These items are: "Do you have difficulty to balance your responsibilities at work with your domestic responsibilities?", "Does your work leave you without enough free time to perform activities related to your family?" "Do your domestic responsibilities leave you without time to develop activities related to your work?".

Subject Age: Measured in terms of years.

Child care: This was measured using one question, developed and used by Bedeian et al (1988), on a Likert-type five-point scale (ranging from ' 0 ' to ' 4 ' where ' 0 'represents no satisfaction and ' 4 ' representing 'total satisfaction'. The question was: "Are you satisfied with the domestic support dedicated to your children (nannies, housekeepers, relatives who are not the spouse/partner)?"

Gender: Coded '0' for 'men' and '1'for women (Frone et al., 1992a; Frone \& Yardley, 1996). 


\section{Results}

The means, standard deviations, and correlations among study variables are reported in Table 1.

Table 1. Means, Standard deviations and correlations ${ }^{\text {a }}$

\begin{tabular}{|c|c|c|c|c|c|c|c|c|c|c|c|c|}
\hline & Mean & SD & 1 & 2 & 3 & 4 & 5 & 6 & 7 & 8 & 9 & 10 \\
\hline & & & & & & & & & & & & \\
\hline 1.Age & 44.86 & 7.62 & 1.00 & & & & & & & & & \\
\hline 2.Gender & .36 & .48 & -.15 & 1.00 & & & & & & & & \\
\hline $\begin{array}{l}\text { 3.Childcar } \\
\mathrm{e}\end{array}$ & 2.00 & 1.46 & \begin{tabular}{|l|}
-.11 \\
\end{tabular} & .11 & 1.00 & & & & & & & \\
\hline $\begin{array}{l}\text { 4.Type of } \\
\text { work }\end{array}$ & .48 & .77 & .10 & $.23 * *$ & .06 & 1.00 & & & & & & \\
\hline $\begin{array}{l}\text { 5.Workwe } \\
\mathrm{ek}\end{array}$ & 38.32 & 4.46 & $.21^{*}$ & $.23 * *$ & .12 & $\begin{array}{l}.69 * \\
*\end{array}$ & 1.00 & & & & & \\
\hline $\begin{array}{l}\text { 6.Number } \\
\text { of children }\end{array}$ & 2.20 & .78 & $\begin{array}{l}.42 * \\
*\end{array}$ & .02 & -.13 & -.05 & -.01 & 1.00 & & & & \\
\hline $\begin{array}{l}\text { 7.Children } \\
\text { 's Age }\end{array}$ & 2.28 & 1.11 & $\begin{array}{l}.69 * \\
* \\
\end{array}$ & .04 & -.14 & .12 & .10 & $.19 *$ & 1.00 & & & \\
\hline $\begin{array}{l}\text { 8.Organiza } \\
\text { tional } \\
\text { support } \\
\text { programs }\end{array}$ & 2.77 & .78 & -.04 & .11 & $\begin{array}{l}- \\
.19 *\end{array}$ & -.14 & -.12 & -.04 & -.05 & 1.00 & & \\
\hline $\begin{array}{l}\text { 9.Supervis } \\
\text { or Support }\end{array}$ & 3.28 & .97 & .070 & $-.21^{*}$ & .01 & .06 & .09 & -.13 & .09 & .01 & 1.00 & \\
\hline $\begin{array}{l}\text { 10.Work- } \\
\text { Family } \\
\text { Balance }\end{array}$ & 2.69 & .74 & $.18^{*}$ & -.09 & -.06 & -.01 & -.03 & .05 & $\begin{array}{l}.25^{*} \\
*\end{array}$ & $.21^{*}$ & $\begin{array}{l}.23^{*} \\
*\end{array}$ & 1.00 \\
\hline
\end{tabular}

*. Correlation is significant at 0.05 level

**. Correlation is significant at 0.01 level

a. Cells contain zero-order (Pearson) correlations.

Our initial analysis of descriptive statistics table suggests that there was no problem with multicollinearity, because correlations between the variables were less than 0.8 . The highest correlation was 0.69 between type of work and workweek. However, statistical check was performed to see the variance inflation factor (VIF). The VIF it was less than 2, suggesting that multicollinearity should not be a problem (Aiken \& West, 1991; Kennedy, 2008). 
The Moderating Effects of Organizational Programs and Supervisor Support on Work -

Multiple regression analysis was used to test the hypotheses. Table 2 presents the results of hierarchical regression results of moderating effects of organizational programs and supervisor support on work-family balance.

Table 2. Hierarchical Regression results of moderating effects of organizational programs and supervisor support on work-family balance

\begin{tabular}{|c|c|c|c|}
\hline & \multicolumn{3}{|c|}{ Work Family Balance } \\
\hline & Model 1 & Model 2 & Model 3 \\
\hline \multicolumn{4}{|l|}{ Control variables: } \\
\hline Age & $.17^{\dagger}$ & .01 & -.002 \\
\hline Gender & -.06 & -.12 & -.05 \\
\hline Childcare & -.04 & -.01 & .05 \\
\hline \multicolumn{4}{|l|}{ Main variables } \\
\hline Type of work & & -.002 & $1.58 * * *$ \\
\hline Workweek & & -.09 & $-.44 * *$ \\
\hline Number of children & & -.01 & -.12 \\
\hline Children's age & & $.26^{*}$ & .31 \\
\hline $\begin{array}{l}\text { Organizational } \\
\text { Programs }\end{array}$ & & $.24 * *$ & .58 \\
\hline Supervisor Support & & $.20 *$ & $2.98^{*}$ \\
\hline Spouse Support & & $.18^{*}$ & .26 \\
\hline \multicolumn{4}{|l|}{ Moderation variables } \\
\hline $\begin{array}{l}\text { Type of work x } \\
\text { Organizational } \\
\text { Programs }\end{array}$ & & & $-.92 * * *$ \\
\hline $\begin{array}{l}\text { Type of work x } \\
\text { Supervisor Support }\end{array}$ & & & $-.68^{*}$ \\
\hline $\begin{array}{l}\text { Workweek x } \\
\text { Organizational } \\
\text { Programs }\end{array}$ & & & $.46 * * *$ \\
\hline $\begin{array}{l}\text { Workweek x } \\
\text { Supervisor Support }\end{array}$ & & & $.27 *$ \\
\hline $\begin{array}{l}\text { Number of children } \\
\text { X Spouse Support }\end{array}$ & & & .20 \\
\hline $\begin{array}{l}\text { Age of children x } \\
\text { Spouse Support }\end{array}$ & & & -.02 \\
\hline $\mathrm{R}^{2}$ & .04 & .19 & .31 \\
\hline Adjusted $\mathrm{R}^{2}$ & .02 & .12 & .20 \\
\hline F- Value & 1.64 & $2.86^{* * *}$ & $1.48^{* * * *}$ \\
\hline
\end{tabular}




\begin{tabular}{|l|l|l|l|}
\hline$\Delta \mathrm{R}^{2}$ & & .16 & .11 \\
\hline$\Delta \mathrm{F}-$ Value & & 3.23 & 2.84 \\
\hline $\mathrm{df}$ & 3,121 & 10,114 & 16,108 \\
\hline
\end{tabular}

Standardized regression coefficients are reported $* * * \mathrm{p}<.001 ; * * \mathrm{p}<.01 ; * \mathrm{p}<.05 ; \uparrow \mathrm{p}<.10$

When work-family balance is the dependent variable, Column 1 (Step 1) shows the effect of control variables viz., age, gender, and childcare. Of these control variables only age was barely significant $(\beta=.17 ; \mathrm{p}<.10)$. The direct effects model presented in step 2 (Column 2 ) suggests that children's age was significantly related to workfamily balance $(\beta=.26 ; p<.05)$ and other main variables viz. type of work, workweek, and number of children were not significant. However, organizational support programs $(\beta=.24 ; \mathrm{p}<.05)$, supervisor support $(\beta=.20 ; \mathrm{p}<.05)$, and spouse support $(\beta=.18 ; \mathrm{p}<.05)$ were significantly related to work-family balance. The model was significant $(\mathrm{F}=2.86 \mathrm{p}<.001)$ and explained 19 percent of variance in work-family balance $\left(\mathrm{R}^{2}=.19\right.$; Adj $\left.\mathrm{R}^{2}=.12 ; \Delta \mathrm{R}^{2}=.16 ; \Delta \mathrm{F}=3.23, \mathrm{p}<0.001\right)$. These results suggest that children's age, organizational support programs and spouse support explained additional variance of 16 percent when compared to the model involving the control variables only. These results do not support $\mathrm{H} 1, \mathrm{H} 2$, and $\mathrm{H} 3$. The results support $\mathrm{H} 4$.

The moderating effects of organizational support programs, supervisor support, and spouse support were tested and presented in Step 3 (Column 3). Surprisingly, when moderators were presented, main effects became significant. The beta coefficients of type of work $(\beta=1.58 ; p<.001)$ and workweek $(\beta=-.44 ; p<.01)$ were significant. The beta coefficient of supervisor support was also significant $(\beta=2.98 ; \mathrm{p}<.05)$. The coefficient for the interaction term for type of work and organizational support programs was negative and significant $(\beta=-.92 ; \mathrm{p}<.05)$. The beta coefficient for interaction term for type of work and supervisor support was positive and significant $(\beta=.46 ; \mathrm{p}<.001)$. Finally, the interaction term for workweek and supervisor support was positive and significant $(\beta=.27 ; \mathrm{p}<.05)$. The interaction terms for number of children and spouse support and age of children and spouse support was not significant. The regression model is significant, explaining 31 percent of variance in the dependent variable $\left(\mathrm{R}^{2}=.31\right.$; Adj $\left.\mathrm{R}^{2}=.20 ; \Delta \mathrm{R}^{2}=.11 ; \Delta \mathrm{F}=2.84, \mathrm{p}<0.001\right)$. The interaction terms explained additional variation of 20 percent variance in workfamily balance. These results support the moderation hypotheses $\mathrm{H} 1 \mathrm{a}, 12 \mathrm{~b}, \mathrm{H} 2 \mathrm{a}$, and $\mathrm{H} 2 \mathrm{~b}$. The results do not support moderation hypotheses $\mathrm{H} 3 \mathrm{a}$ and $\mathrm{H} 4 \mathrm{a}$.

Figures 2(a), 2(b), 2(c) and 2(d) show the interaction plots by showing the regression lines linking organizational support programs and supervisor support influencing the work-family balance. Fig. 2(a) shows that as the type of work is moving from nonmanagerial to managerial, higher organizational support is associated with higher 
levels of work-family balance. It is interesting to note that for managerial work, increase in organizational support programs slightly lowered the work-family balance. Fig. 2(b) shows that higher levels of supervisor support is associated with higher levels of work-family balance. As the nature of work is progressing from non-managerial to advisory, as the supervisor support is increasing, work-family balance is also increasing. However, when task is moved from advisory to managerial, increase in supervisor support is decreasing the work-family balance. This implies that employees who have managerial work do not perceive supervisor support as a factor that influences work-family balance. Fig. 2(c) shows the relationship between workweek and work-family balance moderated by organizational support programs. Higher levels of organizational support programs are resulting in higher levels of work-family balance even when workweek is low. But as the workweek is becoming lengthier, higher organizational support programs did not increase work-family balance, rather it reduced the balance. This implies that as workweek becomes longer, employees are not in a position to take benefit of organizational support programs. Fig. 2(d) showed similar results with regard to supervisor support.

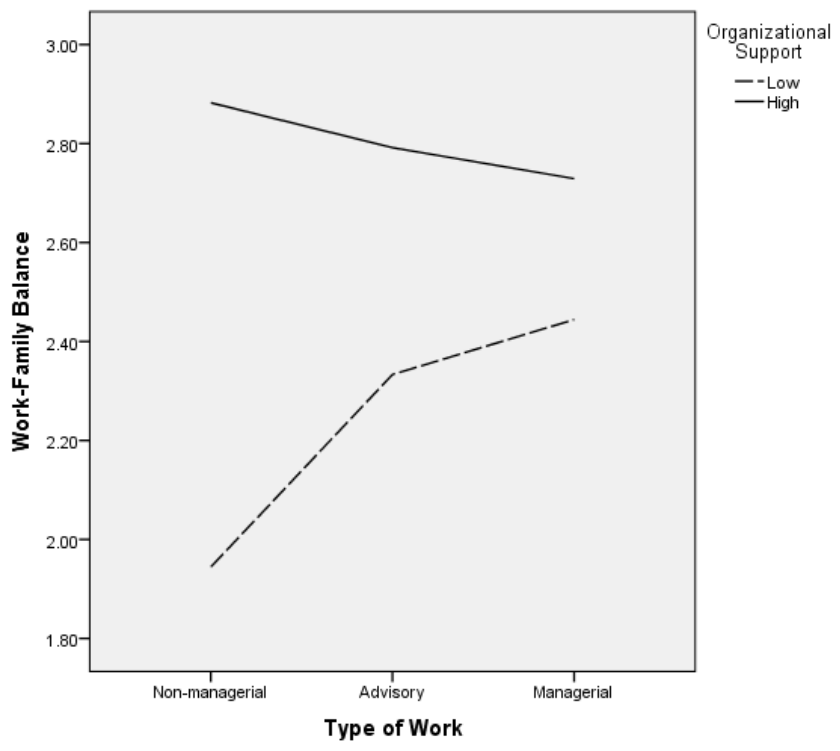

Figure 2(a). Organizational programs as a moderator in the relationship between Type of work and Work-family balance 


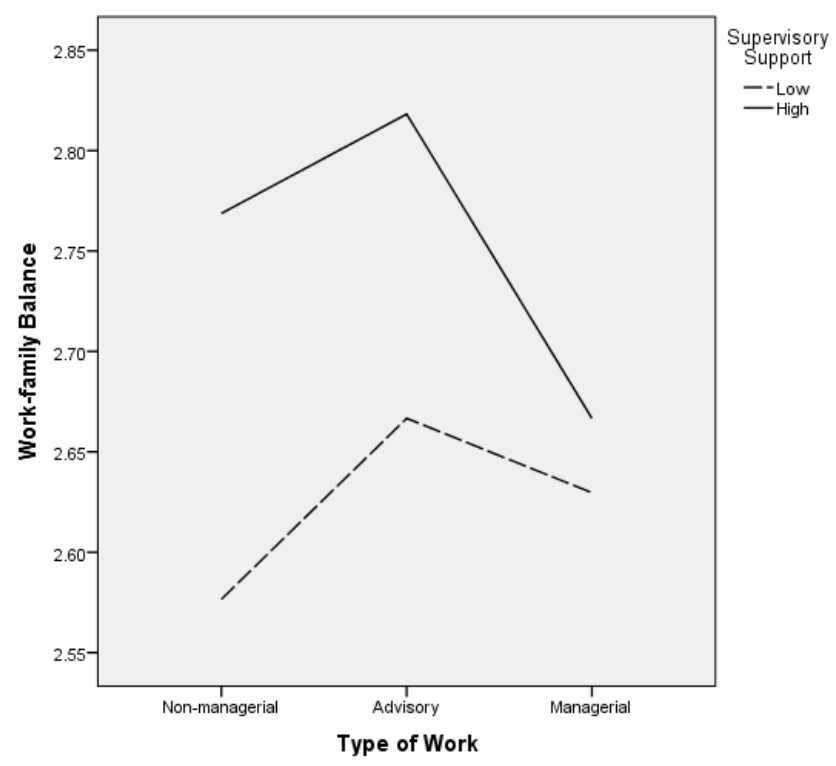

Figure 2(b). Supervisor support as a moderator in the relationship between Type of work and Work-family balance

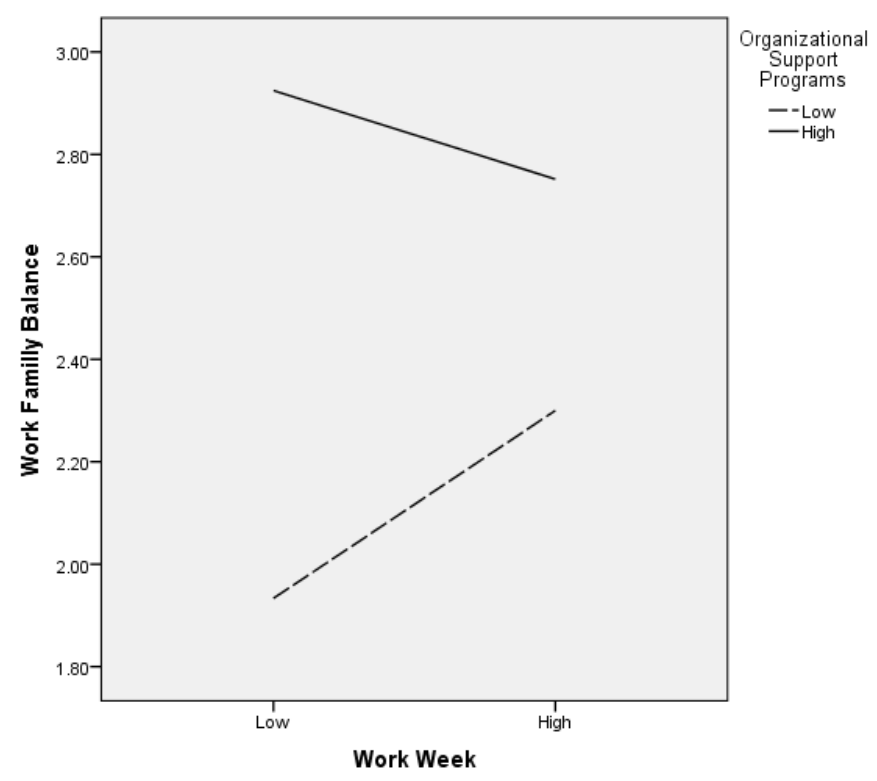

Figure 2(c). Organizational programs as a moderator in the relationship between Workweek and Work-family balance 


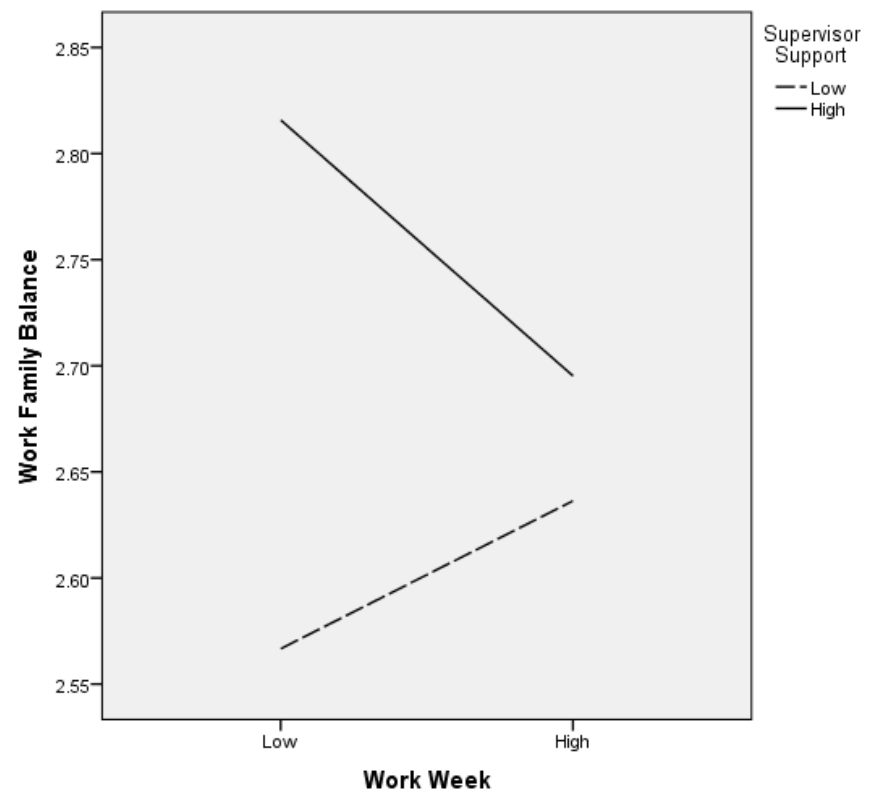

Figure 2(d). Supervisor support as a moderator in the relationship between Workweek and Work-family balance

\section{Discussion}

Work-family balance has become a serious human resource issue these days. In a report by USA Today, over $32 \%$ of employees indicated that balancing work and family has been the leading concern primarily because of increasing number of dualcareer couples, increasing number of single parents who need to take care of their children, and growing need to earn money to have comfortable living (Armor, 2002; Oglesby, 2001; Magnini, 2009).

We developed a conceptual model that has type of work, workweek, age of children, and number of children affecting the work-family balance. In this model, we also examined the moderating effects of supervisor support, organizational support programs, and spouse support. The hierarchical regression reveals interesting results. As the type of work is ranging from non-managerial to managerial positions, high level of supervisor support is not perceived as positive, whereas for non-managerial positions supervisor support increases work-family balance. There is a popular belief that work-life balance is basically a women's problem and this belief is confirmed by interviews of executives by Harvard Business School Students (Grose, 2014).

However, the present research supported specifically the conflict generated between work demands and age of children. One of the reasons why our research supported 
the relationship between age of children and work-family balance is due to the problems caused by the conflict between the responsibilities produced by parenthood and those related to work. The results did not support the hypothesis that spouse support does moderate the relationship between age of children and work-family balance. The primary reason, as has been revealed by interviews of some respondents, is that organizational programs and supervisor support are predominantly considered as superior in maintaining work-family balance. Thus, administrative and managerial actions can be taken by organizations to keep workfamily balance for employees.

The results also corroborate the interviews conducted in this research with regard to differences between spouses in maintaining work-family balance. It was observed that balancing work and family was difficult for employed mothers whose children are in pre-school age (Warren \& Johnson, 1995; Tremblay, 2004). Prior research supports that great deal of human resource management problems are related to emotional and social conflicts perceived by their employees as far as their professional and family duties are concerned (Tremblay, 2003). To minimize the conflict generated between the roles of worker and parent, various organizational measures that can be adopted are support programs such as flextime and virtual office hours to facilitate the work-family balance.

\section{Implications for management}

Striking a happy balance between work demands and family responsibilities has implications for management. Organizations that provide climate for such a happy balance are highly likely to be successful. This is because work-family balance impacts both efficiency of individuals and productivity of organization. Supervisor support and organizational support programs tend to minimize work-family conflict and promote work-family balance. For instance, working long hours, long commutes to and from work, workload, lack of management support, job involvement, and level of importance assigned to one's work, all predict the extent to which work interferes with family. On the other hand, marital status, number of children, level of importance assigned to family roles, and lack of family support all contribute to family interfering with work (McFarland, 2004). Prior research focused on several workplace family-supportive programs (Frone \& Yardley, 1996), organizational support programs (Parayitam \& Kalra, 2008), and work-family balance programs (Tremblay, 2003).

According to Warren \& Johnson (1995), these organizational programs include flextime, job sharing, flextime, job sharing, compressed or reduced workweek, parttime work without benefits, part-time work with pro-rated benefits, work at home or telework, as well as some leave-related policies such as personal days with pay, sick child days with pay, short-term family leave, and extended family leave. Most of the organizations, including the Fortune 500 companies, emphasize the importance of these programs because of the benefits of such programs to both employees and organizations. It is worth remembering that this aspect is present both in people's 
lives as citizens and among managers in working organizations, and it is challenging in any of these situations.

The study demonstrated that organizational programs and supervisor support act as moderators in the relationship between the type of work, workweek, and size of the family in terms of children, and work-family balance. Therefore, it is necessary for the organizations to promote a positive work-life culture at the department-wide and organization-wide levels to implement programs such as telecommuting, flexible working hours etc. Further, organizations need to communicate these benefits to the employees so that they can take advantage of such programs and balance their work demands with life priorities. How well the supervisor and the coworkers balance their own work and demands also has an important role in employee's work-life balance.

Future research. The present research offers many avenues for the future researchers. Since the research on work-family balance is progressing exponentially over the last decade, it is important to conduct longitudinal studies to see how perceptions of work-family balance change over time and also see the antecedents and mediators in the proposed model. The results from the present research can be generalized across all organizations by extending the research to private sector organizations in developing countries. The proportion of financial benefits to organization due to work-family balance are not studied by researchers. Thus, in addition to the individual benefits to employees, the operational implications of work-family balance and identification of any antecedents and mediators in the relationships between work-family balance and benefits provide avenues to future researchers.

\section{References}

Aiken, L. S., \& West, S. G. (1991). Multiple Regression: Testing and interpreting interactions. Newbury Park, CA: Sage.

Antonia Calvo-Salguero,A., Ana Ma Carrasco-González, A.M., \& José María SalinasMartínez de Lecea, J.M. (2010). Relationship between work-family conflict and job satisfaction: The moderating effect of gender and the salience of family and work roles. African Journal of Business Management Vol. 4(7), pp. 1247-1259.

Armour, S. (2002). Workers put family first despite slow economy, jobless fears, USAToday, June 6, 3B

Bedeian, A. G., Bruke, B. G., \& Moffett, R. G.(1988). Outcomes of work-family conflict among married male and female professionals. Journal of Management, 14(3), pp. 475491.

Bellavia. G., \& Frone, M. (2005). Work-family conflict. In J. Barling, E. K. Kelloway, \& M.Frone (Eds.), Handbook of Work Stress, (pp.113-147). Sage Publications: ThousandOaks. 
Carlson, D. S., \& Frone, M. R. (2003). Relation of Behavioral and Psychological Involvement to a New Four-Factor Conceptualization of Work-Family Interference. Journal of Business and Psychology, Vol. 17 (4), pp. 515-535.

Chambel, M. J.; Santos, M. V. (2009). Práticas de conciliação e a satisfação no trabalho: Mediação da facilitação do trabalho na família, Estudos de Psicologia, 26(3), pp. 275 286.

Chenevier, L. (1996). Les variables influençant l'ampleur du conflit "emploi-famille" ressenti par l'employé(e), mémoire de maîtrise, Montréal: Université de Montreal. École des hautes études commerciales, pp. 172.

Clark, S. C. (2000). Work/family border theory: A new theory of work/family balance. Human Relations, 53, pp.747-770

Clarke, M.C., Koch, L.C.,\& Hill, E.J. (2004). The Work-Family Interface: Differentiating Balance and Fit. Family and Consumer Sciences Research Journal, Vol. 33 (2), pp. 121-140.

Ford, M.T, Heinem, F.B, \& Langkamer, K.L (2007). Work and family satisfaction and conflict: A meta-analysis of cross-domain relations. Journal of Applied Psychology Vol. 92, pp. 57-80.

Frone, M. R., Russell, M., \& Cooper, M. L. (1992a) Antecedents and outcomes of workfamily conflict: testing a model of the work-family interface, Journal of Applied Psychology, 77, pp. 65-78.

Frone, M. R., Russell, M., \& Cooper, M. L. (1992b). Prevalence of work-family conflict: are the boundaries asymmetrically permeable? Journal of Organizational Behavior, Vol. 13(1), pp.723-9.

Frone, M. R., Russell, M., \& Cooper, M. L. (1997) M. L. Relation of work-family conflict to health outcomes: A four-year longitudinal study of employed parents. Journal of Occupational and Organizational Psychology, 70 (4), pp. 325-335.

Frone, M. R., \& Yardley, J. K. (1996). Workplace family-supportive programs: Predictors of employed parents' importance ratings. Journal of Occupational and Organizational Psychology, Vol.69 (35) pp. 1-366.

Greenhaus, J. H., \& Beutell, N.J. (1985). Sources of conflict between work and family roles. Academy of Management Review, Vol. 10, pp. 76-88.

Greenhaus, J. H., Collins, K. M., \& Shaw, J. D. (2003). The relation between work-family balance and quality of life. Journal of Vocational Behavior, 63, pp. 510-531.

Greenhaus, J. H., \& Allen, T. D. (2006, March). Work-family balance: Exploration of a concept. Paper presented at the Families and Work Conference, Provo, UT.

Grose, J. (2014). Male Executives Don't Feel Guilt, See Work-Life Balance as a Women's Problem, Harvard Business Review. (http://www.slate.com/blogs/xx_factor/2014/03/05/harvard_business_review_study_on _work_life_balance_male_executives_see_family.html)

Grzywacz, J. G., \& Carlson, D. S. (2007). Conceptualizing Work-Family Balance: Implications for Practice and Research. Advances in Developing Human Resources, Vol. 9, No. 4, pp. 455-471.

Grzywacz, J. G., Frone, M. R., Brewer, C. S., \& Kovner, C.T. (2006). Quantifying workfamily conflict among registered nurses. Research in Nursing \& Health, 29(5), pp. 414426.

Guerin, G., St-onge., Sylvie; Chenvevier, L., Denault, K., \& Deschamps, M. (1997). Le conflit emploi-familie, ses causes et ses conséquences: Résultats d'enquête. Montréal. Université de Montréal, École de relations industrielles, pp. 23. 
The Moderating Effects of Organizational Programs and Supervisor Support on Work Family Balance: Evidence from Brazil

106

Hall, D.T. (1972). A model of coping with role conflict: The role behavior of college educated women, Administrative Science Quarterly, 17, pp. 471-486.

Halpern, D. F. (2005). Psychology at the intersection of work and family: Recommendations for employers, working families, and policymakers. American Psychologist, 60, pp. 397-409.

Harter, J.K., Schmidt, F.L., \& Keyes, C.L.M. (2002). Well-being in the workplace and in relationship to business outcomes: A review of the gallup studies. In C.L.M. Keyes \& J. Haidt (Eds.), Flourishing: Positive psychology and the life well-lived (pp.205-224). Washington, DC: American Psychological Association.

Hill, E. J., Hawkins, A.J., Ferris, M., \& Weitzman, M. (2001). Finding an Extra Day a Week: The Positive Influence of Perceived Job Flexibility on Work and Family Life Balance. Family Relations, Vol. 50 (1), pp. 49-58.

Hudson Resourcing (2005). The case for work/life balance: Closing the gap between policy and practice. Hudson Australia and New Zealand available on www.hudson.com

Kennedy, P (2008). A Guide to Econometrics, Wiley-Blackwell. Malden (Mass).

Kirchmeyer, C. (2000). Work-life initiatives: Greed or benevolence regarding workers' time? In C. L. Cooper \& D. M. Rousseau (Eds.), Trends in organizational behavior (Vol. 7, pp. 79-93). West Sussex, UK: Wiley.

Kopelman, R., Greenhaus, J., \& Connolly, T. (1983). A model of work, family and inter-role conflict: A construct validation study. Organizational Behavior and Human Performance. 32, pp.198-215.

Kossek, E. E., Baltes, B. B., \& Matthews, R. A. (2011). How work-family research can finally have an impact in organizations. Industrial and Organizational Psychology, 4, pp. 352-369.

Lazar, I., Osoian, C., \& Ratiu, P. (2010). The role of work-file balance practices in order to improve organizational performance. European Research Studies, Vol XIII (1), pp. 201-214.

Magnini, V.P. (2009). Understanding and Reducing Work-Family Conflict in the Hospitality Industry, Journal of Human Resources in Hospitality \& Tourism, 8, pp.119-136.

Marks, S. R., \& MacDermid, S. M. (1996). Multiple roles and the self: A theory of role balance. Journal of Marriage and the Family, 58, pp. 417-432.

McFarland, L. A. (2004). Work-Family Balance. The Industrial-Organizational Psychologist, 41(4), pp. 47-53.

Miranda, R. M. A. (2011). O equilíbrio trabalho-família e a interação entre as organizações e seus trabalhadores. Master's Thesis. Fundação Getúlio Vargas - FGV, Escola Brasileira de Administração Pública e de Empresas - EBAPE, Centro de Formação Acadêmica e Pesquisa, 96p.Ngo, H.-Y., Foley, S., \& Loi, R. (2009). Family friendly work practices, organizational climate, and firm performance: A study of multinational corporations in Hong Kong. Journal of Organizational Behavior,30,pp. 665-680.

Oglesby, C. (2001). More options for moms seeking work-family balance. Mother-hood: How Much Is It Worth? Atlanta: CNN

Parayitam, S., \& Kalra, N.K. (2008). From Work-Family Conflicts to Psychological Stress, Job Satisfaction and to Life Satisfaction: a Proposed Integrative Model. Journal of Organizational Culture, Communications and Conflict, Vol. 12 (2), pp. 49-63.

Powell, G. N., Francesco, A. M., \& Ling, Y. (2009). Towards culture-sensitive theories of the work-family interface. Journal of Organizational Behavior, 30, pp.597-616

Rice, R. W., Frone, M. R., \& McFarlin, D. B. (1992). Work-nonwork conflict and the perceived quality of life. Journal of Organizational Behavior, Vol. 13, pp.155-68. 
Spector, P. E., Allen, T. D., Poelmans, S., Lapierre, L. M., Cooper, C. L., O'Driscoll, M., et al. (2007). Cross-national differences in relationships of work demands, job satisfaction and turnover intentions with work-family conflict. Personnel Psychology, 60, pp. 805835.

Tremblay, D. G. (2003). Working Time and Work-family Balancing: A Canadian Perspective. Note 2003-18A, 2003, available at <http://www.teluq.uqam.ca/chaireecosavoir/pdf/NRC03-18A.pdf

Tremblay, D. G. (2004). Work-Family Balance: What are the sources of difficulties and what could be done? Research Note 2004-03A, available at 〈http://www.teluq.uqam.ca/chaireecosavoir/pdf/NRC04-03A.pdf $>$

van Steenbergen, E. F., \& Ellemers, N. (2009). Is managing the work-family interface worthwhile? Benefits for employee health and performance. Journal of Organizational Behavior, 30, pp.617-64.

Voydanoff, P. (2005). Work Demands and Work-to-Family and Family-to-Work Conflict: Direct and Indirect Relationships. Journal of Family Issues, Vol. 26 (6). pp. 707-726.

Warren, J. A., \& Johnson, P. J. (1995). The impact of workplace support on work-family role strain. Family Relations, 44, pp.163-190.

Westman, M., Brough, P., \& Kalliath, T. (2009). Expert commentary on work-life balance and crossover of emotions and experiences: Theoretical and practice advancements. Journal of Organizational Behavior, 30, pp.587-595. 